\title{
Article \\ Composition, Distribution, and Factors Affecting Invasive Plants in Grasslands of Guizhou Province of Southwest China
}

\author{
Qin Yang ${ }^{1}$, Baocheng Jin ${ }^{1}{ }^{\circledR}$, Xuechun Zhao ${ }^{1}$, Chao Chen ${ }^{1}$, Hua Cheng ${ }^{2}$, Huanhuan Wang ${ }^{1}$, Dengming He ${ }^{1}$, \\ Yaoyao Zhang ${ }^{1}$, Jing Peng ${ }^{3}$, Zhongcai $\mathrm{Li}^{3}$ and Min Han ${ }^{3, *}$
}

1 College of Animal Science, Guizhou University, Guiyang 550025, China; 18786658544@163.com (Q.Y.); bcjin@gzu.edu.cn (B.J.); xczhao@gzu.edu.cn (X.Z.); gzgyxgc3855218@163.com (C.C.); 15769354526@163.com (H.W.); hdm18984788070@163.com (D.H.); zyy18375239056@163.com (Y.Z.)

2 School of Tourism, Henan Normal University, Xinxiang 453000, China; chenghua@htu.edu.cn

3 Guizhou Institute of Natural Resources Survey and Planning, Guiyang 550001, China; pj557585@163.com (J.P.); lizhongcai198612@163.com (Z.L.)

* Correspondence: hanmin2022@163.com; Tel.: +86-139-8502-5461

\section{check for}

updates

Citation: Yang, Q.; Jin, B.; Zhao, X.; Chen, C.; Cheng, H.; Wang, H.; He, D.; Zhang, Y.; Peng, J.; Li, Z.; et al. Composition, Distribution, and Factors Affecting Invasive Plants in Grasslands of Guizhou Province of Southwest China. Diversity 2022, 14 167. https://doi.org/10.3390/ d14030167

Academic Editors: Michael Wink and Anatoliy A. Khapugin

Received: 3 February 2022

Accepted: 24 February 2022

Published: 26 February 2022

Publisher's Note: MDPI stays neutral with regard to jurisdictional claims in published maps and institutional affiliations.

Copyright: (C) 2022 by the authors. Licensee MDPI, Basel, Switzerland. This article is an open access article distributed under the terms and conditions of the Creative Commons Attribution (CC BY) license (https:// creativecommons.org/licenses/by/ $4.0 /)$

\begin{abstract}
Southwest China is an important route for invasive species. In this study, 49 invasive plants of 15 families and 41 genera were found within 373 grassland sampling sites of Guizhou Province, a typical karst mountainous region with a high invasion risk located in Southwest China. Invasive plants could be found within over $90 \%$ of the grassland sampling sites, and malignant invasive species were found in $60 \%$ of the sites. In about $30 \%$ of the sampling sites, more than one malignant species coexisted. The malignant invasive species were mainly distributed in the southwestern part of Guizhou Province. Their distribution patterns were affected by environmental and traffic factors; they preferred areas with low elevation, high temperature, high rainfall, high soil nutrient content, and traffic accessibility and could adversely affect plant cover and biomass. Conversely, seriously invasive species and other low-level invasive species had a positive or neutral effect on grassland communities. Therefore, the focus of invasive plant control measures should be on malignant invasive species. Specific control policies and practices, especially in areas with resource-rich environments and well-developed traffic networks, should be carried out to facilitate grassland ecosystem sustainability and to prevent the spread of invasive species to inland China.
\end{abstract}

Keywords: Ageratina adenophora; biodiversity; invasion risk; karst; soil nutrient content; traffic accessibility

\section{Introduction}

Alien invasive species, introduced outside of their natural range either intentionally or unintentionally by human activities [1], can significantly impact ecosystem functions [2-4] and biodiversity [5-8]. In particular, this can lead to a reduction in spontaneous species useful to humans (e.g., crop wild relatives) [9] and can cause economic damage to the invaded habitats $[10,11]$. This means effective and specific management measures are needed to facilitate the sustainability of ecosystems [12-14], which must include the involvement of plant systematics and an improvement of the floristic knowledge on invasive plant species [15].

Grasslands cover more than $13 \%$ of the global land surface [16-18] and are susceptible to alien invasive species. Resource and traffic accessibility are two key factors affecting biological invasion [19-21], and resource-rich habitats often experience more invasion than resource-poor ones [19,22]. For example, Phragmites australis (Cav.) Trin. ex Steud. benefits more from nitrogen addition than its native competitor Spartina pectinata Bosc ex Link [23]. Previous research conducted in the Czech Republic also found that alpinesubalpine grasslands at high elevations are more resistant to alien plant invasions than other grassland types [24]. Traffic networks could promote the spread of invasive plants 
and increase invasibility, depending on traffic volume, road density, road age, road type, and other features of transportation corridors [20,21,25].

China is one of the countries most vulnerable to invasive species (e.g., Eichhornia crassipes (Mart.) Solms, Ageratina adenophora (Spreng.) R.King \& H.Rob., and Solenopsis invicta Buren, 1972) [21,26-29]. Currently, it contains more than 500 invasive plant species (e.g., Solidago Canadensis L., Bidens pilosa L., and Spartina alterniflora Loisel.), including more than 30 malignant invasive species [30-32] (http://www.iplant.cn/ias/, accessed on 1 January 2022). Chinese grasslands contain more than 200 invasive plant species (e.g., Alternanthera philoxeroides (Mart.) Griseb., Chromolaena odorata (L.) R.King \& H.Rob., and Erigeron sumatrensis Retz.) [32].

Southwest China is an important route for invasive species from Southeast Asia to inland China $[30,33,34]$. For example, Ageratina adenophora, native to Central America, has been spreading into Southern China since the 1940s through Burma and Vietnam [21]. The species is dispersing northwards and eastwards at an average speed of $20 \mathrm{~km}$ year $^{-1}$ from the Yunnan-Guizhou Plateau to inland China [35]. Chromolaena odorata, also native to Central America, has spread to Southern China since the 1930s through Thailand [21]. Guizhou Province, located in Southwest China and a typical karst mountainous region, has one of the highest invasion risks in the country [36]. According to a previous study, the province hosts 30 invasive plant species [37], and subsequent studies mainly explored invasive plants in different regions of Guizhou Province and in some nature reserves (including Hongfeng Lake, Dashahe Nature Reserve, and Zhaozishan Nature Reserve, among others). For example, one study found 67 invasive plant species in Tongren City in the northeast [38], whereas other authors found 52 invasive plant species in Hongfeng Lake, Baihua Lake, and the Aha reservoir of Guiyang City in Central Guizhou [39]. Guo et al. determined 46 invasive plant species using 380 plots in the four nature reserves Chishui Alsophila, Xishui, Fanjingshan, and Mayanghe [40]. Other authors found 29, 16, 19, and 112 invasive plant species in Dashahe Nature Reserve [41], Zhaozishan Nature Reserve [42], Bijiang National Wetland Park [43], and Leigong Mountain National Nature Reserve [44]. Other studies focused on the histories, physiological and ecological characteristics, and potential distributions of specific invasive plants, including Ageratina adenophora [35,45-47], Chromolaena odorata [48,49], Soliva anthemifolia R.Br. [50], Xanthium mongolicum Kitag. [50,51], Alternanthera philoxeroides [52,53], Eichhornia crassipes [47], Solanum aculeatissimum Jacq. [47], Ambrosia trifida L. [54], Ageratum conyzoides L. [55], Cyclospermum leptophyllum (Pers.) Sprague ex Britton \& P.Wilson [56], and Mikania micrantha Kunth $[49,57]$. Despite these efforts, there is no complete list, and the distribution patterns of invasive plant species in the grasslands of Guizhou Province, Southwest China, as well as the factors affecting their growth, are largely unclear.

In this context, the objectives of this paper were to (1) provide a catalogue of invasive plants in the grasslands of Guizhou Province, (2) quantify the spatial distribution patterns of these plants, (3) quantify the factors affecting the distribution patterns, and (4) explore appropriate invasive plant management strategies in the grasslands of the Guizhou Province of China.

\section{Materials and Methods}

This study was conducted in Guizhou Province, Southwest China $\left(24^{\circ} 37^{\prime}-29^{\circ} 13^{\prime} \mathrm{N}\right.$, $103^{\circ} 36^{\prime}-109^{\circ} 35^{\prime}$ E; $150-2900 \mathrm{~m}$ elevation; Figure 1). The climate is a humid subtropical monsoon climate, with a mean (1981-2010) annual temperature of $14.2^{\circ} \mathrm{C}$ and a mean annual precipitation of $1069.9 \mathrm{~mm}$. The mean daily temperatures of the coldest (January) and warmest (July) months are 4.4 and $22.2^{\circ} \mathrm{C}$, respectively (data from the China Meteorological Data Center; https:/ / data.cma.cn/, accessed on 11 July 2021). Although forest is the main vegetation type, there are about 200,000 hectares of grassland including natural grasslands, artificial grasslands, and abandoned fields in Guizhou Province (data from the third national land survey of China). According to the FAO 90 taxonomy [58], the main soils are Haplic Alisols, Haplic Luvisols, and Dystric Regosols. The terrain is a 
hilly mountainous karst area, and the grassland plant community is mainly composed of Arthraxon hispidus (Thunb.) Makino, Artemisia argyi H.Lév. \& Vaniot, Imperata cylindrica (L.) P.Beauv., Eragrostis pilosa (L.) P.Beauv., Miscanthus floridulus (Labill.) Warb., Ficus tikoua Bureau, Erigeron annuus (L.) Desf, Erigeron acris L., and Agrimonia pilosa Ledeb.

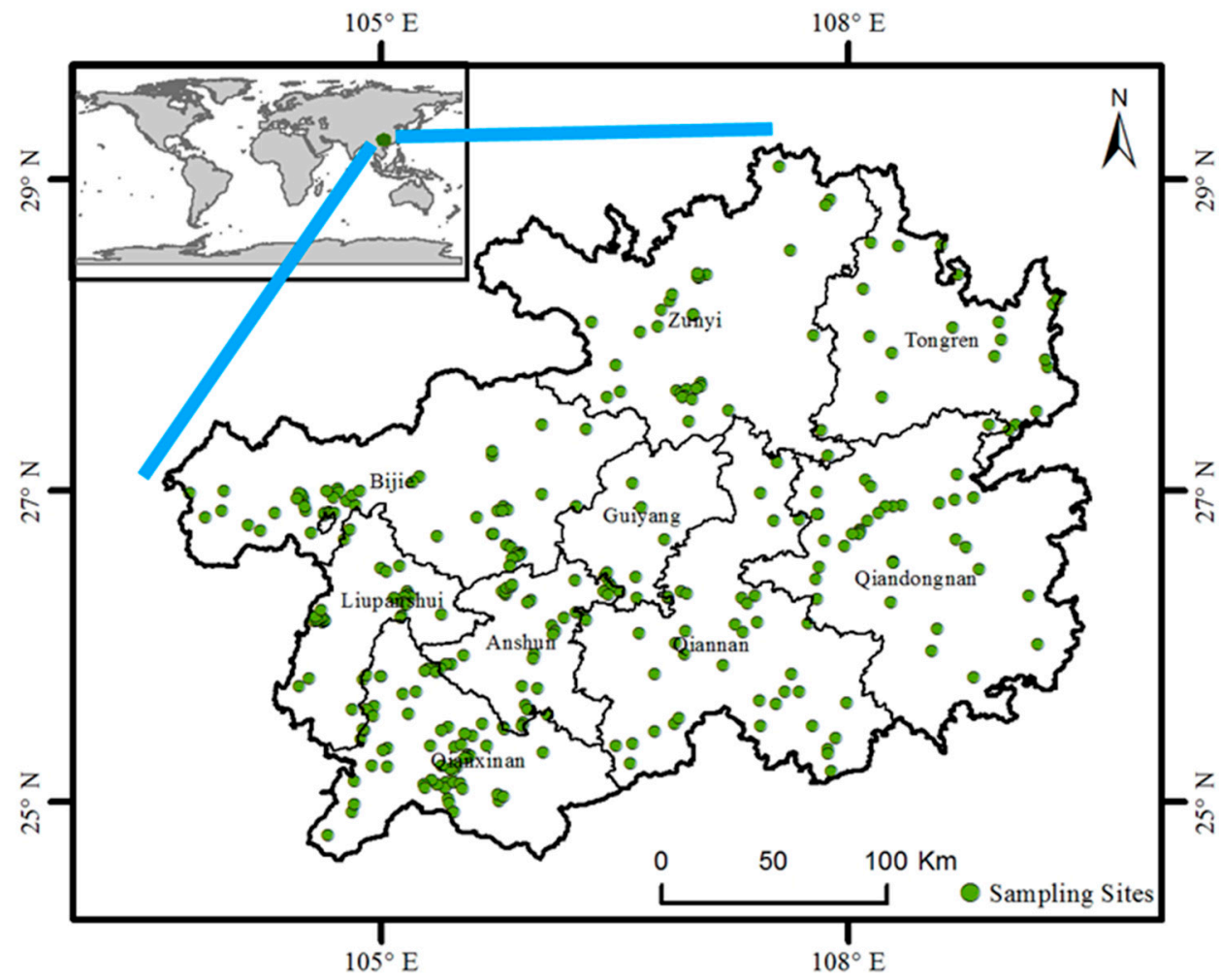

Figure 1. Distribution of the sampling sites in Guizhou Province, Southwest China. The geographic coordinate system of the map is the China Geodetic Coordinate System 2000.

Overall, 373 sampling sites, covering nearly all counties of Guizhou Province, were established from July to October in 2021. Within each sampling site, 20 sampling plots $(1 \times 1 \mathrm{~m}$ in size and well separated from each other) were surveyed to determine the plant community composition. At the same time, within each site, three sampling plots $(1 \times 1 \mathrm{~m}$ in size and well separated from each other) were established, and their numbers of species, average plant height, plant cover, and plant biomass for both invasive and noninvasive species were determined. The aboveground vegetation in each plot was collected by species. Plant samples were dried for $90 \mathrm{~h}$ at a temperature of $60{ }^{\circ} \mathrm{C}$ and weighed to determine aboveground plant biomass. The publications "Alien invasive plants in Chinese grassland" [32], "Invasive alien species of China" (website: http:/ / www.iplant.cn/ias/, accessed on 1 January 2022), and "The checklist of the Chinese invasive plants" [30,31] were used to determine whether a plant was an invasive plant. The invasion levels of each plant species were classified according to previous publications [30,31], using the following five levels: 1, malignant invasive species, that cause malignant economic and ecological damage at a national scale and affect more than one geographical region; 2, seriously invasive species, that cause serious economic and ecological damage at a national scale and affect more than one geographical region; 3, local invasive species, that cause local economic and ecological damage within one or more geographical regions but not nationwide; 4 , general invasive species, that will not cause serious or obvious economic and ecological damage based on their biological and ecological characteristics and will most likely not cause new invasions; 5, species requiring further observation; these are newly found, newly reported, or poorly understood species whose invasion trends require further observation. 
We collected the corresponding environmental factors of each site, including mean (1970-2000) annual temperature, mean (1970-2000) annual precipitation, elevation, and SOC (Table 1) [58,59]. We also collected traffic network data (including railways, expressways, national roads, and country roads) from the GIM-Cloud (geographical information monitoring cloud platform, http:/ / www.dsac.cn/, accessed on 1 January 2022), and the distance from each sampling site to the closest road was calculated using ArcMap (version 10.8, ESRI, Redlands, CA, USA). Their Pearson correlations with plant invasion intensity (namely the number and biomass of invasive species) were calculated using IBM SPSS Statistics (version 19, IBM).

Table 1. Possible environmental and traffic network factors affecting invasive plant distribution.

\begin{tabular}{|c|c|}
\hline Item & Source \\
\hline $\begin{array}{l}\text { Mean annual temperature } \\
\text { Mean annual precipitation }\end{array}$ & $\begin{array}{l}\text { WorldClim Data version } 2.1 \text { (https:/ / www.worldclim.org/, } \\
\text { accessed on } 1 \text { January 2022) }\end{array}$ \\
\hline Elevation & $\begin{array}{c}\text { ASTER GDEM (https: / / www.gscloud.cn/, accessed on } \\
\text { 1 January 2022) }\end{array}$ \\
\hline SOC & $\begin{array}{c}\text { Harmonized World Soil Database version } 1.21 \\
\text { (http:/ / webarchive.iiasa.ac.at/Research/LUC/External-World- } \\
\text { soil-database/, accessed on } 1 \text { January 2022) }\end{array}$ \\
\hline Traffic Network & $\begin{array}{l}\text { Geographical Information Monitoring Cloud Platform } \\
\text { (http:/ / www.dsac.cn/, accessed on } 1 \text { January 2022) }\end{array}$ \\
\hline
\end{tabular}

\section{Results}

\subsection{Catalogue of Invasive Plants}

Overall, 49 invasive plant species, belonging to 15 families and 41 genera, were found within the 373 grassland sampling sites (Table 2). Asteraceae (19 species), Poaceae (6 species), Amaranthaceae (5 species), and Fabaceae (4 species) were the main families, with Ipomoea L. (3 species), Trifolium Tourn. ex L. (2 species), Sonchus L. (2 species), Ambrosia L. (2 species), Crassocephalum Moench (2 species), Solanum L. (2 species), and Veronica L. (2 species) being the main genera (Table 2). Trifolium repens L., Bidens Pilosa, and Ageratina adenophora appeared in more than $20 \%(41.29,39.14$, and $23.06 \%)$ of the sampling sites. Cyperus rotundus L. and Praxelis clematidea (Griseb.) R.King \& H.Rob. appeared in 10-20\% (15.01 and 14.75\%) of the sampling sites, whereas Erigeron sumatrensis, Sonchus wightianus DC., Crassocephalum crepidioides (Benth.) S.Moore, Solanum quitoense Lam., Chromolaena odorata, and Avena fatua L. were present in 5-10\% of the sampling sites. Trifolium pretense L., Alternanthera philoxeroides, and Ageratum conyzoides, along with 10 other species, were found in 1-5\% of the sampling sites. As relatively rare species, Euphorbia dentate Michx., Dysphania ambrosioides (L.) Mosyakin \& Clemants, Solanum aculeatissimum, Ambrosia trifida, Ambrosia artemisiifolia L., and Solidago Canadensis, along with other species, appeared in less than $1 \%$ of the sampling sites. There was no significant difference in the average frequencies among the five invasive levels.

Invasive plants were found in over 90\% (90.35\%) of the grassland sampling sites, whereas malignant invasive plants were detected in about $60 \%$ (59.79\%) of all sites. Furthermore, in about $30 \%$ (29.23\%) of the sampling sites, more than one malignant invasive species coexisted. There may be two (57 sites, 15.28\%), three (39 sites, $10.46 \%$ ), four (12 sites, $3.22 \%$ ), or five ( 1 site, $0.27 \%$ ) malignant invasive plant species within one site.

Overall, 15 invasive plants, including Chromolaena odorata, Erigeron sumatrensis, Bidens pilosa, and others, were classified as malignant invasive plants (Level 1), whereas 12 species, including Trifolium pratense L., Avena fatua, and others, were classified as seriously invasive plants (Level 2). Five species, namely Pennisetum purpureum Schumach., Paspalum dilatatum Poir., Oenothera rosea Aiton, Veronica persica Poir., and Euphorbia dentate, were local invasive plants (Level 3). Ten species, including Medicago sativa L., Sida acuta Burm. fil., and others, were classified as general invasive species (Level 4), and seven species, including 
Amorpha fruticose L., Axonopus compressus (Sw.) P.Beauv., and others, were species requiring further investigations (Level 5).

Table 2. Catalogue of invasive plants in grasslands of Guizhou Province, Southwest China. The five invasion levels are as follows: malignant invasion (Level 1), serious invasion (Level 2), local invasion (Level 3), general invasion (Level 4), and plants requiring further observation (Level 5) [30,31].

\begin{tabular}{|c|c|c|c|c|c|}
\hline Rank & Family & Name & Invasive Level & Source Area & Frequency $(\%)$ \\
\hline 1 & Asteraceae & Bidens pilosa $\mathrm{L}$. & 1 & America & 39.14 \\
\hline 2 & Asteraceae & $\begin{array}{c}\text { Ageratina adenophora (Spreng.) } \\
\text { R.King \& H.Rob }\end{array}$ & 1 & Mexico & 23.06 \\
\hline 3 & Asteraceae & $\begin{array}{c}\text { Praxelis clematidea (Griseb.) } \\
\text { R.King \& H.Rob }\end{array}$ & 1 & South America & 14.75 \\
\hline 4 & Asteraceae & Erigeron sumatrensis Retz. & 1 & South America & 9.65 \\
\hline 5 & Asteraceae & $\begin{array}{l}\text { Chromolaena odorata (L.) } \\
\text { R.King \& H.Rob }\end{array}$ & 1 & Mexico & 6.97 \\
\hline 6 & Amaranthaceae & $\begin{array}{c}\text { Alternanthera philoxeroides (Mart.) } \\
\text { Griseb }\end{array}$ & 1 & Brazil & 4.02 \\
\hline 7 & Asteraceae & Ageratum conyzoides L. & 1 & Tropical America & 3.75 \\
\hline 8 & Convolvulaceae & Ipomoea purpurea (L.) Roth & 1 & America & 2.95 \\
\hline 9 & Amaranthaceae & $\begin{array}{l}\text { Dysphania ambrosioides (L.) } \\
\text { Mosyakin \& Clemants }\end{array}$ & 1 & Tropical America & 0.8 \\
\hline 10 & Convolvulaceae & Ipomoea cairica (L.) Sweet & 1 & America & 0.27 \\
\hline 11 & Asteraceae & Ambrosia artemisiifolia L. & 1 & $\begin{array}{l}\text { Central America, } \\
\text { North America }\end{array}$ & 0.27 \\
\hline 12 & Asteraceae & Ambrosia trifida $\mathrm{L}$. & 1 & North America & 0.27 \\
\hline 13 & Asteraceae & Parthenium hysterophorus L. & 1 & Tropical America & 0.27 \\
\hline 14 & Asteraceae & Solidago canadensis L. & 1 & North America & 0.27 \\
\hline 15 & Amaranthaceae & Amaranthus spinosus L. & 1 & Tropical America & 0.27 \\
\hline 16 & Fabaceae & Trifolium repens L. & 2 & $\begin{array}{c}\text { North Africa, } \\
\text { Central Asia, } \\
\text { West Asia, Europe }\end{array}$ & 41.29 \\
\hline 17 & Asteraceae & $\begin{array}{l}\text { Crassocephalum crepidioides (Benth.) } \\
\text { S.Moore }\end{array}$ & 2 & Africa & 7.51 \\
\hline 18 & Poaceae & Avena fatua $\mathrm{L}$. & 2 & $\begin{array}{l}\text { South Europe, } \\
\text { Mediterranean }\end{array}$ & 6.17 \\
\hline 19 & Fabaceae & Trifolium pratense $\mathrm{L}$. & 2 & $\begin{array}{c}\text { North Africa, } \\
\text { Central Asia, Europe }\end{array}$ & 4.83 \\
\hline 20 & Apiaceae & Daucus carota L. & 2 & Europe & 2.68 \\
\hline 21 & Solanaceae & Solanum aculeatissimum Jacq. & 2 & Brazil & 0.8 \\
\hline 22 & Amaranthaceae & Celosia argentea $\mathrm{L}$. & 2 & India & 0.8 \\
\hline 23 & Nyctaginaceae & Mirabilis jalapa L. & 2 & Tropical America & 0.54 \\
\hline 24 & Amaranthaceae & Gomphrena celosioides L. & 2 & Tropical America & 0.54 \\
\hline 25 & Convolvulaceae & Ipomoea triloba L. & 2 & India & 0.27 \\
\hline 26 & Cactaceae & Opuntia dillenii (Ker Gawl.) Haw. & 2 & Caribbean & 0.27 \\
\hline 27 & Asteraceae & Tridax procumbens L. & 2 & Tropical America & 0.27 \\
\hline 28 & Poaceae & Paspalum dilatatum Poir. & 3 & South America & 3.22 \\
\hline 29 & Poaceae & Pennisetum purpureum Schumach. & 3 & Africa & 2.68 \\
\hline
\end{tabular}


Table 2. Cont.

\begin{tabular}{|c|c|c|c|c|c|}
\hline Rank & Family & Name & Invasive Level & Source Area & Frequency $(\%)$ \\
\hline 30 & Euphorbiaceae & Euphorbia dentata Michx. & 3 & North America & 0.8 \\
\hline 31 & Scrophulariaceae & Veronica persica Poir. & 3 & West Asia & 0.54 \\
\hline 32 & Onagraceae & Oenothera rosea Aiton & 3 & Tropical America & 0.54 \\
\hline 33 & Cyperaceae & Cyperus rotundus L. & 4 & India & 15.01 \\
\hline 34 & Asteraceae & Sonchus oleraceus L. & 4 & $\begin{array}{c}\text { Europe, } \\
\text { Mediterranean }\end{array}$ & 7.77 \\
\hline 35 & Poaceae & Setaria palmifolia (J. Koenig) Stapf & 4 & Africa & 3.22 \\
\hline 36 & Asteraceae & Sonchus asper (L.) Hill & 4 & $\begin{array}{c}\text { Europe, } \\
\text { Mediterranean }\end{array}$ & 1.34 \\
\hline 37 & Fabaceae & Medicago sativa L. & 4 & West Asia & 1.07 \\
\hline 38 & Malvaceae & Sida acuta Burm. fil. & 4 & Tropical America & 0.54 \\
\hline 39 & Scrophulariaceae & Veronica arvensis $\mathrm{L}$. & 4 & $\begin{array}{c}\text { South Europe, } \\
\text { West Asia }\end{array}$ & 0.27 \\
\hline 40 & Asteraceae & Cichorium intybus L. & 4 & $\begin{array}{c}\text { Europe, Central Asia, } \\
\text { West Asia, } \\
\text { North Africa }\end{array}$ & 0.27 \\
\hline 41 & Asteraceae & Helianthus tuberosus L. & 4 & North America & 0.27 \\
\hline 42 & Asteraceae & Senecio vulgaris L. & 4 & Europe & 0.27 \\
\hline 43 & Solanaceae & Solanum quitoense Lam. & 5 & Asia & 7.51 \\
\hline 44 & Poaceae & Axonopus compressus (Sw.) P.Beauv. & 5 & Tropical America & 3.49 \\
\hline 45 & Asteraceae & Crepis tectorum $\mathrm{L}$. & 5 & Europe & 1.34 \\
\hline 46 & Iridaceae & Sisyrinchium rosulatum E.P.Bicknell & 5 & North America & 0.54 \\
\hline 47 & Asteraceae & $\begin{array}{l}\text { Crassocephalum rubens } \\
\text { (Juss. ex Jacq.) S.Moore }\end{array}$ & 5 & Tropical Africa & 0.54 \\
\hline 48 & Poaceae & Chrysopogon zizanioides (L.) Roberty & 5 & India & 0.27 \\
\hline 49 & Fabaceae & Amorpha fruticosa $\mathrm{L}$. & 5 & America & 0.27 \\
\hline
\end{tabular}

All malignant invasive plant species originated from America (including Brazil, Mexico, South America, Tropical America, Central America, and North America). Five of the seriously invasive plants originated from America and seven from Africa, Europe, and Asia. Three of the local invasive plants originated from America and two from Africa and Asia. Two of the generally invasive plants originated from America and eight from Africa, Europe, and Asia. Three species requiring further investigations originated from America and four from Africa, Europe, and Asia (Table 2).

\subsection{Distribution of Invasive Plants}

Regarding the malignant invasive species, Bidens pilosa covered most regions of Guizhou Province (Figure 2a), whereas Ageratina adenophora was mainly found in the southwestern part (Figure $2 \mathrm{~b}$ ). Praxelis clematidea was mainly reported from the southern part (Figure 2c) and Erigeron sumatrensis from the eastern part (Figure 2d). Chromolaena odorata had its main distribution range in the southeastern part (Figure 2e). Alternanthera philoxeroides was mainly found in the central and eastern parts (Figure 2f), whereas Ageratum conyzoides was mostly located in the central and southern parts (Figure 2g) and Ipomoea purpurea (L.) Roth in the southwest part (Figure 2h). Occasional species, such as Dysphania ambrosioides, Ambrosia artemisiifolia, Solidago canadensis, Parthenium hysterophorus L., Amaranthus spinosus L., and Ipomoea cairica (L.) Sweet were found in different regions (Figure 2i). 

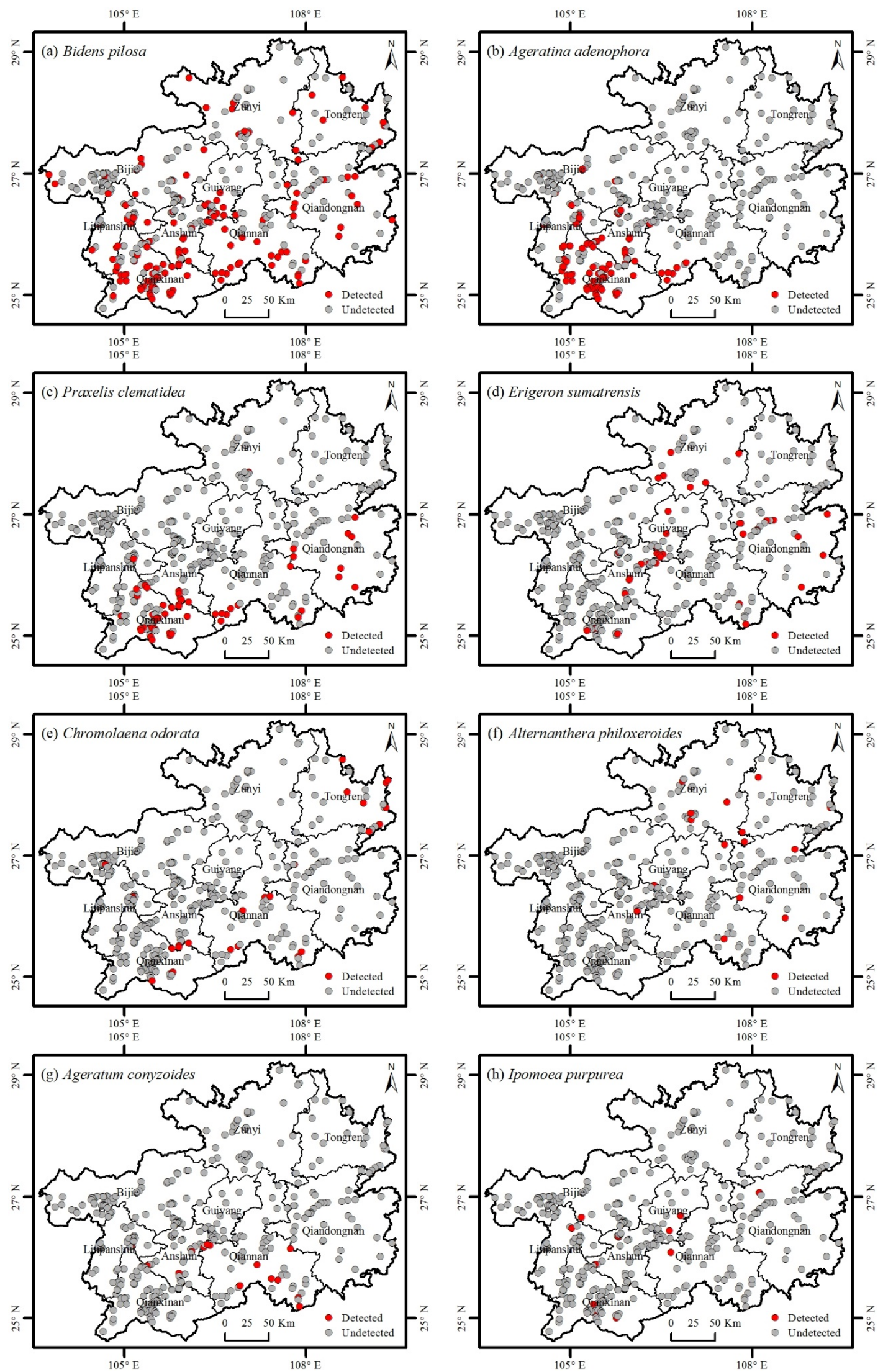

Figure 2. Cont. 


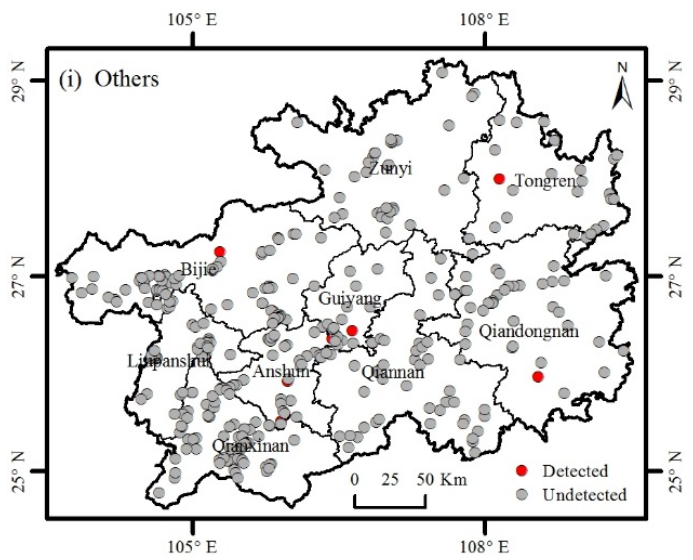

Figure 2. Distribution of malignant invasive species (Level 1). Red and grey dots indicate detected and undetected invasive species, respectively.

Regarding the seriously invasive species, Trifolium repens, Crassocephalum crepidioides, Avena fatua, and Trifolium pretense covered most regions of Guizhou Province (Figure 3a-d), whereas Daucus carota L. was concentrated in the central part of Guizhou Province (Figure 3e). Occasional species, such as Solanum aculeatissimum, Celosia argentea L., Gomphrena celosioides L., Mirabilis jalapa L., Tridax procumbens L., and Opuntia dilleniid (Ker Gawl.) Haw., were found in various different regions (Figure 3f).
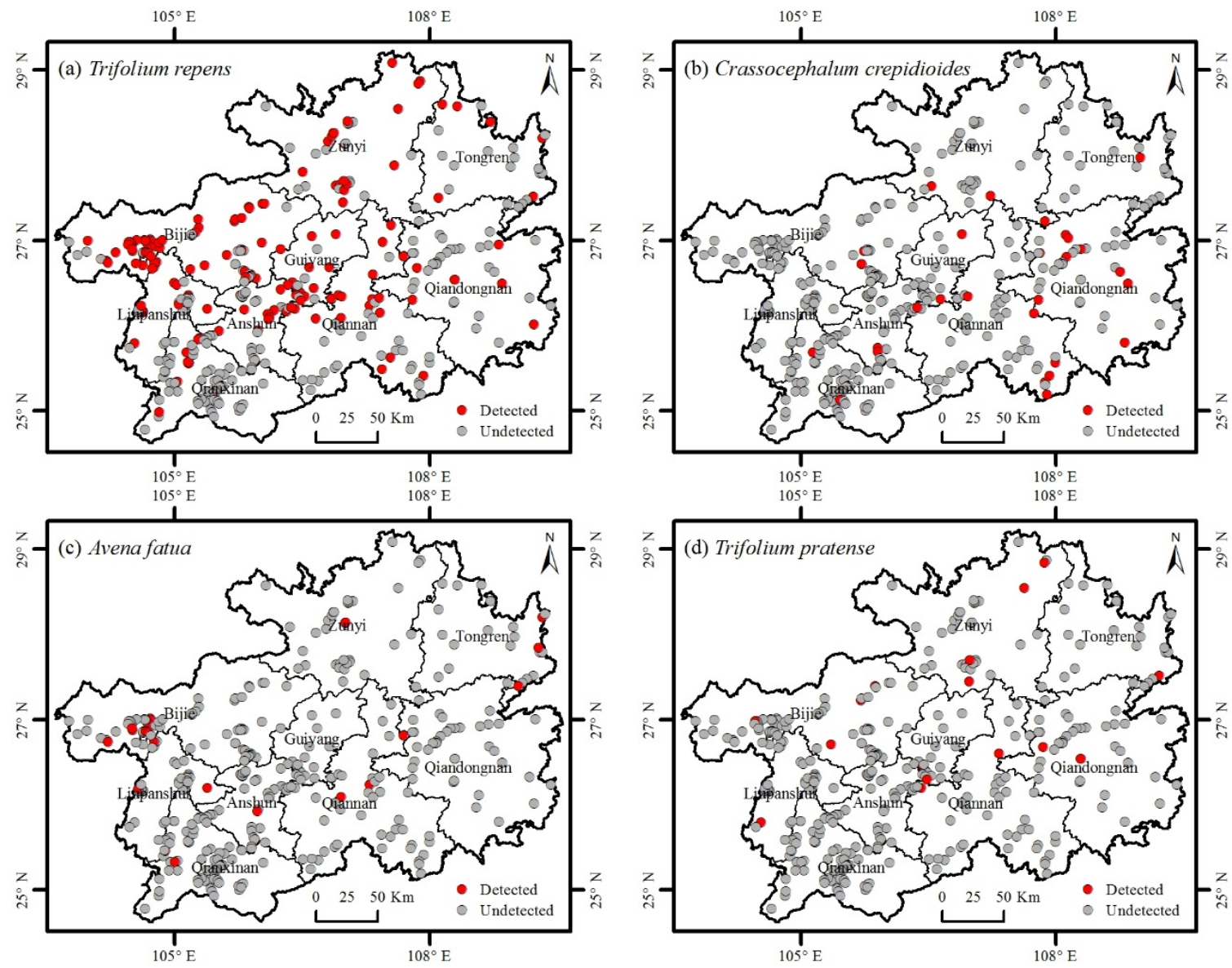

Figure 3. Cont. 

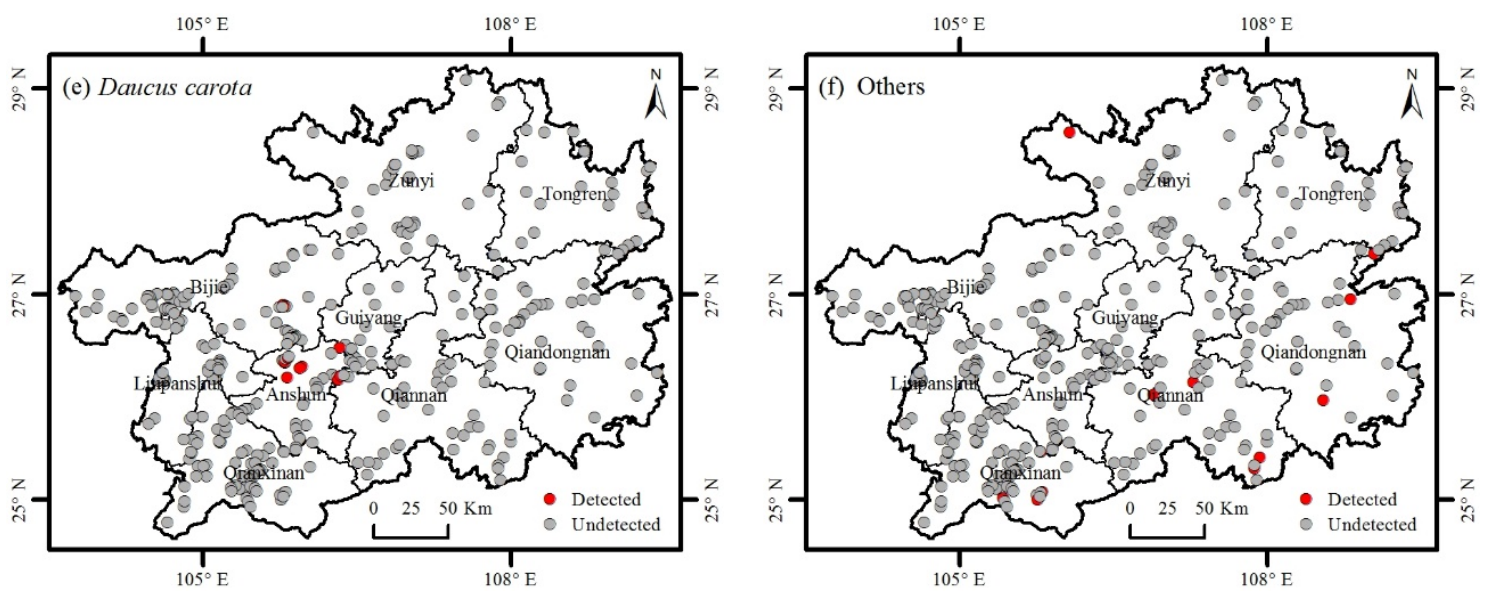

Figure 3. Distribution of seriously invasive plants (Level 2). Red and grey dots indicate detected and undetected invasive species, respectively.

Regarding locally invasive plants, Paspalum dilatatum was mainly found in the central part of Guizhou Province (Figure 4a) and Pennisetum purpureum in the central part (Figure $4 \mathrm{~b}$ ). Occasional species, such as Euphorbia dentata Michx., Oenothera rosea, and Veronica persica, were located in different regions (Figure 4c).
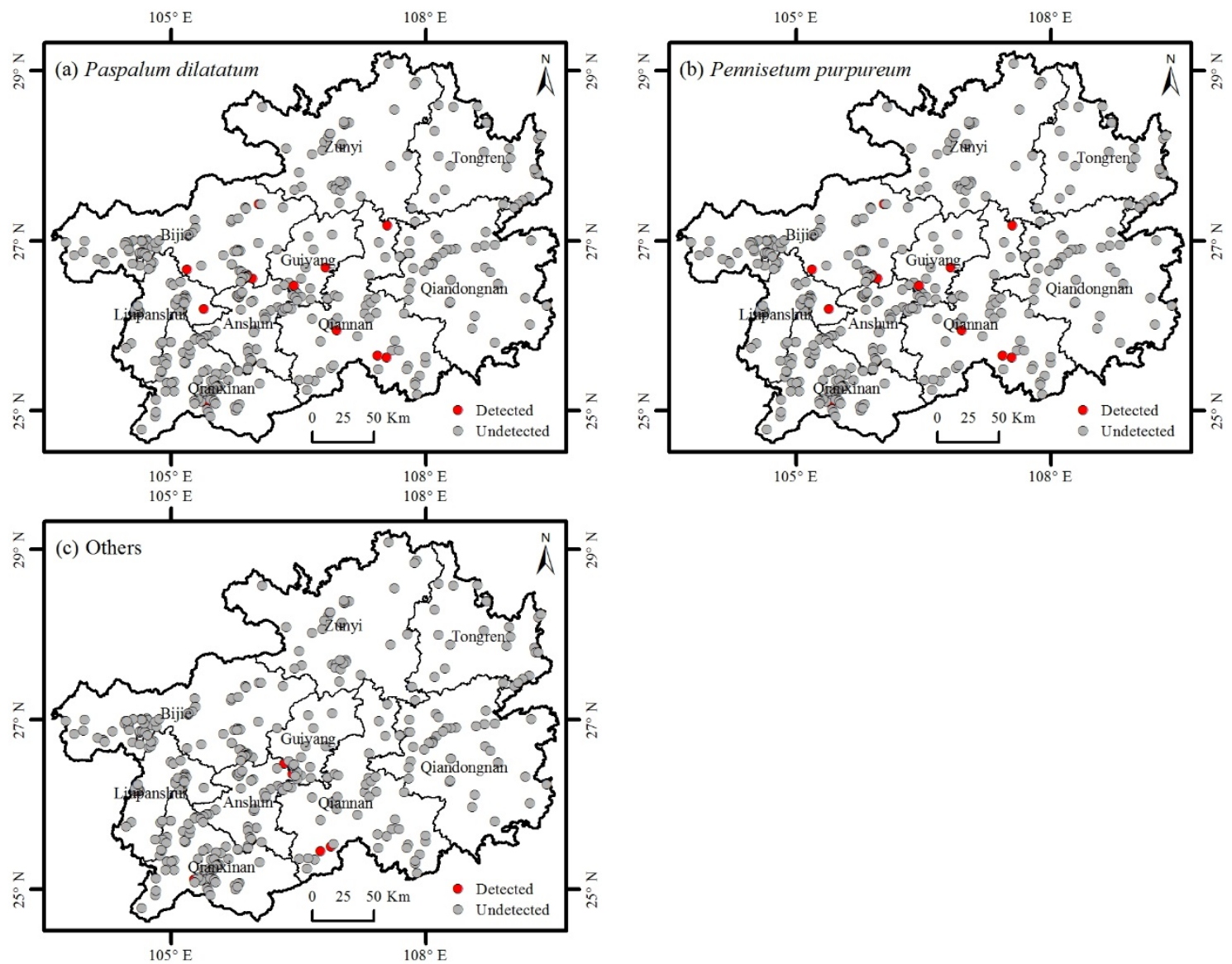

Figure 4. Distribution of locally invasive plants (Level 3). Red and grey dots indicate detected and undetected invasive species, respectively.

Regarding general invasive plants, Cyperus rotundus and Sonchus oleraceus L. were present in most regions of Guizhou Province (Figure 5a,b), whereas Setaria palmifolia (J. Koenig) Stapf was mainly found in the southern part (Figure 5c). Occasional species, in- 
cluding Sonchus asper (L.) Hill, Medicago sativa, Sida acuta, Cichorium intybus L., Senecio vulgaris L., Helianthus tuberosus L., and Veronica arvensis L., were located in different regions (Figure 5d).
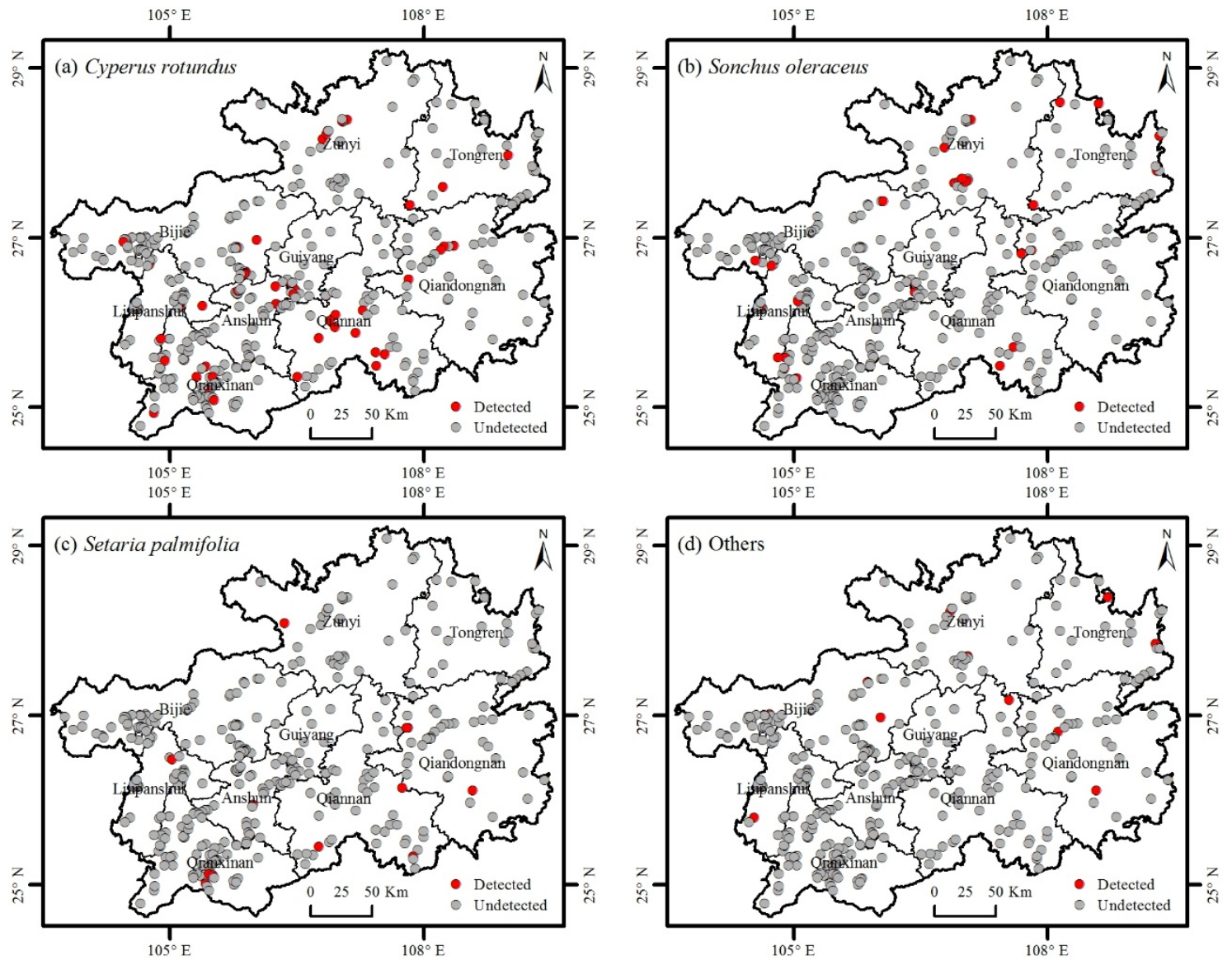

Figure 5. Distribution of generally invasive plants (Level 4). Red and grey dots indicate detected and undetected invasive species, respectively.

Regarding the invasive plants requiring further investigations, Solanum quitoense and Axonopus compressus were mainly found in the southwestern part of Guizhou Province (Figure 6a,b) and Crepis tectorum L. in the western part (Figure 6c). Occasional species, including Crassocephalum rubens (Juss. ex Jacq.) S.Moore, Sisyrinchium rosulatum E.P.Bicknell, Amorpha fruticose, and Chrysopogon zizanioides (L.) Roberty were located in various different regions (Figure 6d).

\subsection{Factors Affecting the Distribution of Invasive Plants}

At the sampling plot scale, we found $0.43 \pm 0.49$ (mean \pm std) invasive species within each $1 \times 1 \mathrm{~m}$ sampling plot, including $0.17 \pm 0.36$ malignant invasive species, $0.19 \pm 0.34$ seriously invasive species, $0.01 \pm 0.08$ locally invasive species, $0.05 \pm 0.14$ generally invasive species, and $0.01 \pm 0.06$ species requiring further observation. The total biomass of all invasive species within each sampling plot was $11.08 \pm 25.35 \mathrm{~g}$, among which malignant invasive species, seriously invasive species, locally invasive species, generally invasive species, and species requiring further observation accounted for $3.28 \pm 11.54 \mathrm{~g}$, $4.71 \pm 16.98 \mathrm{~g}, 0.40 \pm 5.16 \mathrm{~g}, 2.64 \pm 14.86 \mathrm{~g}$, and $0.05 \pm 0.43 \mathrm{~g}$, respectively.

For the malignant invasive species, there was a significant negative correlation between plant invasion intensity (namely the number and biomass of invasive species) and elevation, and a positive correlation for precipitation, temperature, SOC, and distance to roads (Table 3). For the seriously invasive species, there was a significant positive correlation between plant invasion intensity and elevation and a negative correlation for precipitation, temperature, and SOC (Table 3). The correlations with distance to roads were 
inconsistent for different types of roads (Table 3). The invasion intensity-environmental factors correlation was weak for locally invasive plants, generally invasive plants, and invasive plants requiring further investigations (Table 3).
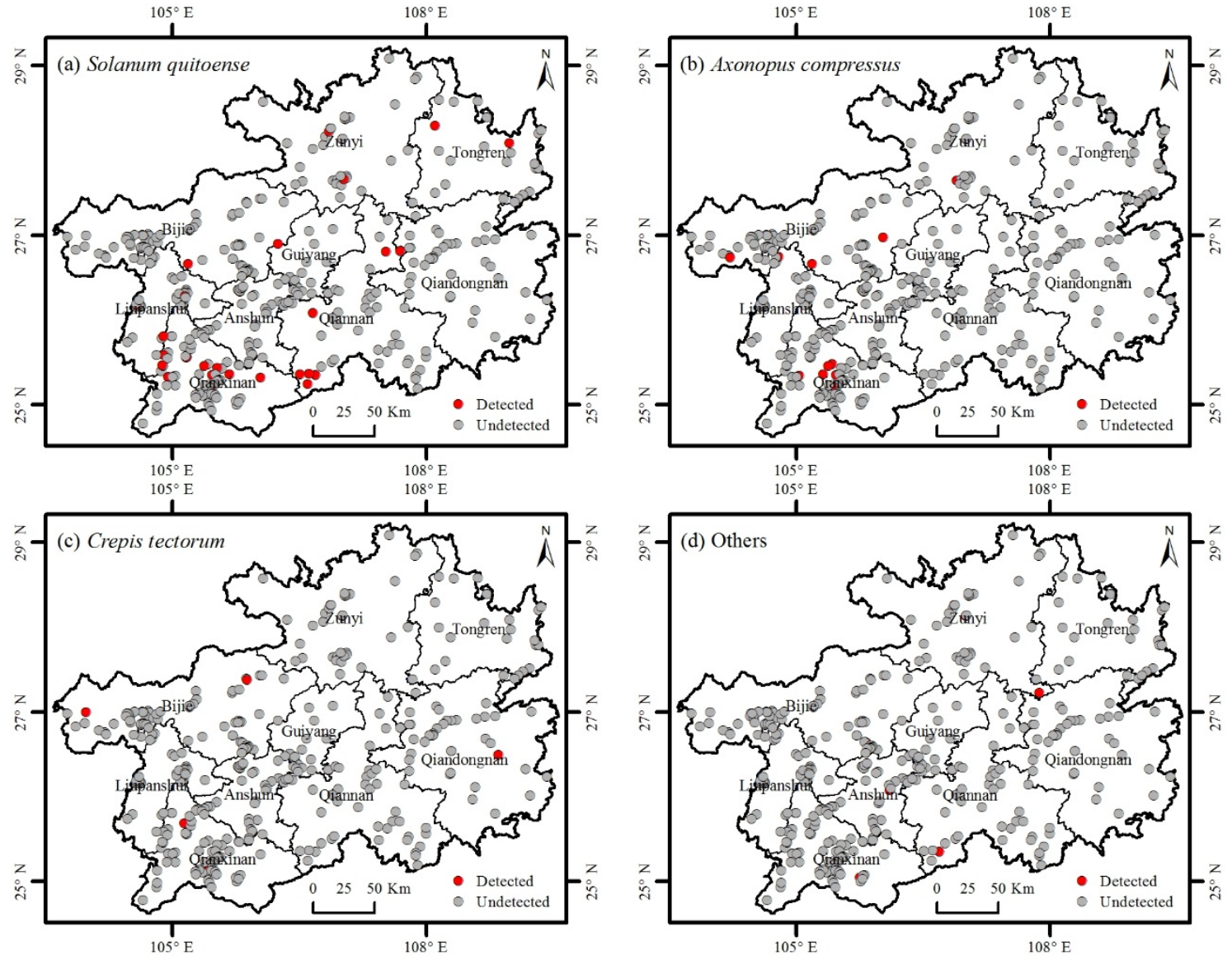

Figure 6. Distribution of invasive plants requiring further investigations (Level 5). Red and grey dots indicate detected and undetected invasive species, respectively.

Table 3. Pearson's correction coefficients between plant invasion intensity and environmental factors.

* indicates significant correlation at the level of 0.05 .

\begin{tabular}{cccccccccc}
\hline & $\begin{array}{c}\text { Invasive } \\
\text { Level }\end{array}$ & Elevation & Precipitation & Temperature & SOC & $\begin{array}{c}\text { Distance to } \\
\text { Railways }\end{array}$ & $\begin{array}{c}\text { Distance to } \\
\text { Expressways }\end{array}$ & $\begin{array}{c}\text { Distance to } \\
\text { National } \\
\text { Roads }\end{array}$ & $\begin{array}{c}\text { Distance } \\
\text { to Country } \\
\text { Roads }\end{array}$ \\
\hline & 1 & $-0.24^{*}$ & $0.30^{*}$ & $0.39^{*}$ & $0.18^{*}$ & $0.14^{*}$ & 0.03 & $0.18^{*}$ & 0.01 \\
Number of & 2 & $0.38^{*}$ & $-0.33^{*}$ & $-0.44^{*}$ & $-0.11^{*}$ & -0.06 & $0.16^{*}$ & 0.01 & $-0.16^{*}$ \\
Invasive & 3 & $0.11^{*}$ & -0.02 & -0.08 & 0.00 & 0.00 & -0.01 & $0.21^{*}$ & -0.08 \\
Species & 4 & -0.01 & 0.02 & 0.02 & 0.00 & -0.10 & -0.07 & -0.04 & 0.03 \\
& 5 & 0.05 & 0.04 & -0.01 & -0.06 & 0.01 & -0.08 & -0.01 & 0.04 \\
Biomass of & 1 & $-0.15^{*}$ & $0.22^{*}$ & $0.26^{*}$ & $0.14^{*}$ & 0.09 & 0.00 & 0.08 & 0.06 \\
Invasive & 2 & $0.23^{*}$ & $-0.23^{*}$ & $-0.25^{*}$ & -0.07 & 0.04 & 0.05 & -0.04 & $-0.11^{*}$ \\
Species & 3 & 0.03 & -0.03 & -0.02 & -0.03 & -0.04 & 0.03 & 0.10 & -0.03 \\
& 4 & 0.00 & 0.01 & 0.00 & 0.09 & -0.09 & -0.08 & -0.08 & 0.03 \\
& 5 & 0.04 & 0.07 & 0.02 & -0.05 & -0.02 & -0.07 & 0.02 & -0.06 \\
\hline
\end{tabular}

Regarding the malignant invasive species, there were significant negative correlations between invasion intensity and plant cover and biomass, but these correlations were not significant for number of species and plant height (Table 4). There also was a significant positive correlation between the invasion intensity of seriously invasive species and number of species, and a negative correlation for plant height, but these correlations were not significant for plant cover and biomass (Table 4). There was a trend toward negative 
correlations between the invasion intensity of local invasive species and plant height, a positive correlation between the invasion intensity of general invasive species and plant cover, and a negative correlation between the invasion intensity of species requiring further observation and plant cover and biomass (Table 4).

Table 4. Pearson's correlation coefficients between invasion intensity and plant community characteristics. * indicates significant correlation at the level of 0.05 .

\begin{tabular}{cccccc}
\hline & Invasion Level & $\begin{array}{c}\text { Number of } \\
\text { Species }\end{array}$ & Height & Plant Cover & Biomass \\
\hline & 1 & -0.09 & 0.08 & $-0.13^{*}$ & $-0.15^{*}$ \\
Number of & 2 & $0.33^{*}$ & $-0.46^{*}$ & 0.09 & -0.05 \\
Invasive Species & 3 & 0.06 & $-0.10^{*}$ & -0.02 & -0.07 \\
& 4 & -0.01 & -0.07 & 0.07 & -0.04 \\
& 5 & -0.01 & -0.06 & $-0.14^{*}$ & $-0.11^{*}$ \\
Biomass of & 1 & -0.07 & 0.05 & $-0.13^{*}$ & -0.10 \\
Invasive Species & 2 & $0.10 *$ & $-0.32 *$ & 0.08 & -0.05 \\
& 3 & -0.01 & -0.06 & -0.01 & -0.02 \\
& 4 & -0.06 & -0.06 & $0.13 *$ & 0.07 \\
& 5 & 0.00 & -0.08 & $-0.12 *$ & -0.10 \\
\hline
\end{tabular}

\section{Discussion}

\subsection{Grasslands in Guizhou Province Are Severely Invaded by Non-Native Species}

Southwest China is an important route for invasive species [30,33,34]. Guizhou Province, located in Southwest China, is an important part of the invasion route and has one of the highest invasion risks [36]. Although previous studies have found that the number of alien invasive plant species in Guizhou Province is lower than that in the southwestern neighboring provinces of Yunnan and Guangxi, the number is close to that of other inland neighboring provinces such as Hunan and Chongqing and exceeds that of inland provinces such as Gansu and Shanxi [30]. This paper provides a catalogue of invasive plants in the grasslands of Guizhou Province of China and quantifies their spatial distribution patterns.

Invasive plants (15 families, 41 genera, 49 species) in the grasslands of Guizhou Province accounted for about $30 \%$ of the grassland plants in China (41 families, 123 genera, 183 species) [32] and were more numerous than those within the grasslands of three northeastern provinces in China (12 families, 35 genera, 38 species) [60]. However, their number was much lower than that of the invasive plants found within the SerengetiMara ecosystem in East Africa (245 species) [61], the Chilean Mediterranean grasslands (66 species) [62], and the Leigong Mountain National Nature Reserve (38 families, 88 genera, 112 species) [44] and close to that of Hongfeng Lake, Baihua Lake, and the Aha Reservoir of Guiyang City in central Guizhou (52 invasive plants from 20 families) [39]. However, it was greater than that of the invasive plants found in other nature reserves of Guizhou Province [40-43].

Fifteen invasive plant species, namely Chromolaena odorata, Erigeron sumatrensis, Bidens pilosa, Ageratum conyzoides, Praxelis clematidea, Ambrosia trifida, Ambrosia artemisiifolia, Solidago canadensis, Parthenium hysterophorus, Ageratina adenophora, Dysphania ambrosioides, Alternanthera philoxeroides, Amaranthus spinosus, Ipomoea cairica, and Ipomoea purpurea, were classified as malignant invasive plants. They all originate from America (including Brazil, Mexico, South America, Tropical America, Central America, and North America), which is in agreement with previous studies reporting that Southern and Northern America were the first and second source areas, respectively, for invasive plant species in China [30]. Species originating from America account for more than $50 \%$ of the grassland invasive plants [32], suggesting that species from America should be the focus of invasive plant management policies and practices in the future in Guizhou Province. 
The malignant invasive species could adversely affect plant cover and biomass. This is consistent with previous research showing a negative correlation between grassland cover and the intensity of invasion [63]. The ecological processes leading to these correlations warrant future research. Invasive plant species were present in more than $90 \%$ of the grassland sampling sites, and malignant invasive species were found in about $60 \%$ of these sites. In about $30 \%$ of the sampling sites, more than one malignant species coexisted. There were 0.43 (or $11.08 \mathrm{~g}$ in weight) invasive species, including 0.17 (or $3.28 \mathrm{~g}$ in weight) malignant invasive species within each $1 \times 1 \mathrm{~m}$ sampling plot; these percentages indicate over 20,000 and 6000 tons of invasive species and malignant invasive species in Guizhou Province, respectively, given that the total grassland area is about 200,000 hectares (data from the Third National Land Survey of China). Therefore, this paper addressed the severe plant invasion problem of the grassland of the Guizhou Province.

\subsection{Distribution Pattern, Affecting Factors, and Management Implications}

The malignant invasive species were mainly distributed in the southwestern part of Guizhou Province. This is consistent with the spreading trend for these newly introduced malignant invasion plants from southwest to inland China [35,36,45,46,64]. These malignant invasive species prefer areas with low elevation, high temperature, high rainfall, high soil nutrient contents, and traffic accessibility, which is consistent with their biological characteristics [64-66] and the results of previous studies [19-21,67,68]. This is also consistent with previous studies conducted in the Czech Republic, where alpine-subalpine grasslands were more resistant to alien plant invasions [24]. Although these malignant invasive species do not affect the number of species and plant height, they could adversely affect plant cover and biomass, suggesting that they have negative impacts on the local grassland ecosystem.

The seriously invasive species tended to be distributed in areas with high elevation, low temperature, low rainfall, and low soil nutrient content. Most likely, this is due to the fact that these plants are mainly forage plants, such as Trifolium repens, Avena fatua, Trifolium pretense, and Daucus carota [69], and have been intentionally introduced to these areas to improve grassland [70,71]. Therefore, the seriously invasive species could enrich plant biodiversity without reducing the height, cover, and biomass of local grassland ecosystems, suggesting that they have positive impacts.

Regarding other low-level invasive species (including local invasive plants, general invasive plants, and invasive plants requiring further investigation), their plant invasion intensity was lower than that of malignant and seriously invasive species. Although there was a trend toward negative correlations between the invasion intensity of local invasion species and plant height, and a positive correlation between the invasion intensity of generally invasive species and plant cover, this was inconsistent for the number and biomass of invasive species. The invasion intensity of species requiring further observation, however, surprisingly showed obvious negative effects on the plant cover and biomass of grassland. Considering the intensity and invasion levels [30,31], and their correlations with plant community characteristics, we suggest that these low-level invasive species had an effect close to neutral on grassland ecosystems, but further research is needed. At the same time, the interactions and correlations among environmental factors (such as between temperature and elevation) deserve further studies.

In summary, the focus of invasive plant control measures should be on malignant invasive species, which could adversely affect plant cover and biomass. In particular, the five malignant invasive species (Bidens pilosa, Ageratina adenophora, Praxelis clematidea, Erigeron sumatrensis, and Chromolaena odorata) that appeared in over $5 \%$ of the sampling sites require further attention. Seriously invasive species and other low-level invasive species were positive or neutral to grassland ecosystems. Given the wide distribution of invasive plants in this area, specific control policies and practices, especially in areas with resource-rich environments and a well-developed traffic network, should be carried out to 
facilitate grassland ecosystem sustainability and to prevent the spread of invasive species to inland China.

Author Contributions: Conceptualization, Q.Y., M.H., B.J. and X.Z.; methodology, Q.Y., B.J., X.Z., H.C., H.W., D.H., C.C. and Y.Z.; software, Q.Y., M.H., J.P. and Z.L.; validation, Q.Y., B.J., X.Z. and J.P.; investigation, Q.Y., B.J., X.Z., H.C., H.W., D.H., Y.Z., J.P., Z.L., C.C. and M.H.; writing-original draft preparation, Q.Y., M.H., B.J., X.Z. and H.C. All authors have read and agreed to the published version of the manuscript.

Funding: This work was supported by grants from the National Natural Science Foundation of China (31700390) and Guizhou University (2016-75), Qian Ke He Zhicheng ([2020]1Y076 and [2021]YIBAN503) from the Science and Technology Department of Guizhou Province, and the Guizhou provincial grassland resource survey project from the Guizhou Department of Natural Resources.

Institutional Review Board Statement: Not applicable.

Informed Consent Statement: Not applicable.

Data Availability Statement: Not applicable.

Conflicts of Interest: The authors declare no conflict of interest.

\section{References}

1. Elton, C.S.; Simberloff, D.; Ricciardi, A. The Ecology of Invasions by Animals and Plants, 2nd ed.; Springer Nature Switzerland AG: Cham, Switzerland, 2020.

2. Pejchar, L.; Mooney, H.A. Invasive species, ecosystem services and human well-being. Trends Ecol. Evol. 2009, 24, 497-504. [CrossRef] [PubMed]

3. Bauer, J.T. Invasive species:“back-seat drivers” of ecosystem change? Biol. Invasions 2012, 14, 1295-1304. [CrossRef]

4. Walsh, J.R.; Carpenter, S.R.; Vander Zanden, M.J. Invasive species triggers a massive loss of ecosystem services through a trophic cascade. PNAS 2016, 113, 4081-4085. [CrossRef] [PubMed]

5. Hejda, M.; Pyšek, P.; Jarošík, V. Impact of invasive plants on the species richness, diversity and composition of invaded communities. J. Ecol. 2009, 97, 393-403. [CrossRef]

6. McNeely, J. Invasive species: A costly catastrophe for native biodiversity. Land Use Water Resour. Res. 2001, 2, 1-10. [CrossRef]

7. Hejda, M.; Sadlo, J.; Kutlvasr, J.; Petrik, P.; Vitkova, M.; Vojik, M.; Pysek, P.; Pergl, J. Impact of invasive and native dominants on species richness and diversity of plant communities. Preslia 2021, 93, 181-201. [CrossRef]

8. Morelli, T.L.; Brown-Lima, C.J.; Allen, J.M.; Beaury, E.M.; Fusco, E.J.; Barker-Plotkin, A.; Laginhas, B.B.; Quirion, B.R.; Griffin, B.; McLaughlin, B.; et al. Translational invasion ecology: Bridging research and practice to address one of the greatest threats to biodiversity. Biol. Invasions 2021, 23, 3323-3335. [CrossRef]

9. Perrino, E.V.; Wagensommer, R.P. Crop Wild Relatives (CWRs) threatened and endemic to Italy: Urgent actions for protection and use. Biology 2022, 11, 193. [CrossRef]

10. Hoffmann, B.D.; Broadhurst, L.M. The economic cost of managing invasive species in Australia. NeoBiota 2016, 31, 1-18. [CrossRef]

11. Epanchin-Niell, R.S. Economics of invasive species policy and management. Biol. Invasions 2017, 19, 3333-3354. [CrossRef]

12. Mehta, S.V.; Haight, R.G.; Homans, F.R.; Polasky, S.; Venette, R.C. Optimal detection and control strategies for invasive species management. Ecol. Econ. 2007, 61, 237-245. [CrossRef]

13. Larson, D.L.; Phillips-Mao, L.; Quiram, G.; Sharpe, L.; Stark, R.; Sugita, S.; Weiler, A. A framework for sustainable invasive species management: Environmental, social, and economic objectives. J. Environ. Manag. 2011, 92, 14-22. [CrossRef] [PubMed]

14. Moon, K.; Blackman, D.A.; Brewer, T.D. Understanding and integrating knowledge to improve invasive species management. Biol. Invasions 2015, 17, 2675-2689. [CrossRef]

15. Stinca, A.; Musarella, C.M.; Rosati, L.; Laface, V.L.A.; Licht, W.; Fanfarillo, E.; Wagensommer, R.P.; Galasso, G.; Fascetti, S.; Esposito, A.; et al. Italian vascular flora: New findings, updates and exploration of floristic similarities between regions. Diversity 2021, 13, 600. [CrossRef]

16. Asner, G.P.; Elmore, A.J.; Olander, L.P.; Martin, R.E.; Harris, A.T. Grazing systems, ecosystem responses, and global change. Annu. Rev. Env. Resour. 2004, 29, 261-299. [CrossRef]

17. Gong, P.; Wang, J.; Yu, L.; Zhao, Y.; Zhao, Y.; Liang, L.; Niu, Z.; Huang, X.; Fu, H.; Liu, S.; et al. Finer resolution observation and monitoring of global land cover: First mapping results with Landsat TM and ETM+ data. Int. J. Remote Sens. 2013, 34, 2607-2654. [CrossRef]

18. Yu, L.; Wang, J.; Gong, P. Improving $30 \mathrm{~m}$ global land-cover map FROM-GLC with time series MODIS and auxiliary data sets: A segmentation-based approach. Int. J. Remote Sens. 2013, 34, 5851-5867. [CrossRef]

19. Funk, J.L.; Vitousek, P.M. Resource-use efficiency and plant invasion in low-resource systems. Nature 2007, 446, 1079-1081. [CrossRef] 
20. Muirhead, J.R.; Minton, M.S.; Miller, W.A.; Ruiz, G.M. Projected effects of the Panama Canal expansion on shipping traffic and biological invasions. Divers. Distrib. 2015, 21, 75-87. [CrossRef]

21. Yan, X.; Zhenyu, L.; Gregg, W.P.; Dianmo, L. Invasive species in China-an overview. Biodivers. Conserv. 2001, 10, 1317-1341. [CrossRef]

22. Gross, K.L.; Mittelbach, G.G.; Reynolds, H.L. Grassland invasibility and diversity: Responses to nutrients, seed input, and disturbance. Ecology 2005, 86, 476-486. [CrossRef]

23. Rickey, M.A.; Anderson, R.C. Effects of nitrogen addition on the invasive grass Phragmites australis and a native competitor Spartina pectinata. J. Appl. Ecol. 2004, 41, 888-896. [CrossRef]

24. Chytrý, M.; Jarošík, V.; Pyšek, P.; Hájek, O.; Knollová, I.; Tichý, L.; Danihelka, J. Separating habitat invasibility by alien plants from the actual level of invasion. Ecology 2008, 89, 1541-1553. [CrossRef]

25. Lemke, A.; Kowarik, I.; von der Lippe, M. How traffic facilitates population expansion of invasive species along roads: The case of common ragweed in Germany. J. Appl. Ecol. 2019, 56, 413-422. [CrossRef]

26. Jenkins, P.T.; Mooney, H.A. The United States, China, and invasive species: Present status and future prospects. Biol. Invasions 2006, 8, 1589-1593. [CrossRef]

27. Weber, E.; Sun, S.-G.; Li, B. Invasive alien plants in China: Diversity and ecological insights. Biol. Invasions 2008, 10, 1411-1429. [CrossRef]

28. Liu, J.; Liang, S.; Liu, F.; Wang, R.; Dong, M. Invasive alien plant species in China: Regional distribution patterns. Divers. Distrib. 2005, 11, 341-347. [CrossRef]

29. Ding, J.Q.; Mack, R.N.; Lu, P.; Ren, M.X.; Huang, H.W. China's booming economy is sparking and accelerating biological invasions. Bioscience 2008, 58, 317-324. [CrossRef]

30. Yan, X.; Liu, Q.; Shou, H.; Zeng, X.; Zhang, Y.; Chen, L.; Liu, Y.; Ma, H.; Qi, S.; Ma, J. The categorization and analysis on the geographic distribution patterns of Chinese alien invasive plants. Biodivers. Sci. 2014, 22, 667-676. [CrossRef]

31. Ma, J. The Checklist of the Chinese Invasive Plants; Higher Education Press: Beijing, China, 2013.

32. Cao, J.; Xu, H.; Pan, X.; Rong, Y. Study on the status of invasive plants in Chinese grassland. Acta Agrestia Sin. 2020, $28,1-11$. [CrossRef]

33. Bai, Y.; Cao, X.; Chen, C.; Hu, B.; Liu, F. Potential distribution areas of alien invasive plant Flaveria bidentis (Asteraceae) in China. Chin. J. Appl. Ecol. 2009, 20, 2377-2383.

34. Wang, R.; Wang, J.-F.; Qiu, Z.-J.; Meng, B.; Wan, F.-H.; Wang, Y.-Z. Multiple mechanisms underlie rapid expansion of an invasive alien plant. New Phytol. 2011, 191, 828-839. [CrossRef] [PubMed]

35. Sang, W.G.; Zhu, L.; Axmacher, J.C. Invasion pattern of Eupatorium adenophorum Spreng in southern China. Biol. Invasions 2010, 12, 1721-1730. [CrossRef]

36. Chen, J.; Ma, F.; Zhang, Y.; Wang, C.; Xu, H. Spatial distribution patterns of invasive alien species in China. Glob. Ecol. Conserv. 2021, 26, e01432. [CrossRef]

37. Tu, Y. Biological invasion-Alien invasive plants in Guizhou. Environ. Prot. Technol. 2002, 8, 1-4, 10. [CrossRef]

38. Liu, M.; Chen, M.; Gao, J.; Zheng, Y. Composition and source of alien plant species in Tongren city. Guizhou Agric. Sci. 2021, 49, 96-103.

39. Shi, D.; Li, C. Alien plant invasion situation in "two lakes and one reservoir" ecological functional area of Guiyang and prevention measures. Guizhou Agric. Sci. 2011, 39, 94-98.

40. Guo, C.; Zhu, J.; Liu, X.; Zhao, C.; Li, J. Contrasting biodiversity of invasive herbs inside and outside nature reserves in Guizhou. Biodivers. Sci. 2021, 29, 596-604. [CrossRef]

41. Lin, M.; Liu, Z.; Han, F.; Ren, M.; Zhang, J. The investigation of invasive plants in Guizhou Dashahe nature reserve. J. Weed Sci. 2008, 1, 31-32, 51. [CrossRef]

42. Zhou, Y.; Wei, Z.; Zhang, R.; Deng, T. Current situation and investigation of invasive plants in Zhaozishan nature reserve. Guizhou Agric. Sci. 2019, 47, 36-42.

43. Yan, X.; Zhang, B.; Liu, B.; Wu, J.; Yang, H. Investigation and control measures of foreign pests in Guizhou Bijiang national wetland park. Anhui Agric. Sci. Bull. 2021, 27, 146-149. [CrossRef]

44. Yang, C.; Li, F.; Yu, D.; Liang, Y. A preliminary study on alien invasive plants in Leigong mountain national nature reserve of Guizhou province. For. By-Prod. Spec. China 2017, 3, 79-84. [CrossRef]

45. Yu, S.; Tian, M.; Zhang, N.; Qiu, J.; Zhou, Q.; Ban, Q. Prediction of suitable area of invasive plant Eupatorium adenophorum in Guizhou. For. Pest Dis. 2022, 41, 1-7. [CrossRef]

46. Huang, J.; Wan, Y.; Liu, Z. The damage situation and control countermeasures for Eupatorium adenophorum Spreng in Guizhou province. Guizhou For. Sci. Technol. 2007, 52-56.

47. Li, R.; Zha, L.; Wu, C.; Qin, L. Three alien invasive plants in Bijie City: Their outbreaks and control measures. Mod. Agric. Sci. Technol. 2015, 209-210.

48. Yu, S.; Tian, M.; Zhang, N.; Qiu, J.; Zhou, Q.; Ban, Q.; Chen, Y. Prediction and risk analysis of suitable growth area of invasive plant Chromolaena odorata in Guizhou. J. West China For. Sci. 2021, 50, 125-130. [CrossRef]

49. Fang, Y.; Zhang, X.; Wei, H.; Wang, D.; Chen, R.; Wang, L.; Gu, W. Predicting the invasive trend of exotic plants in China based on the ensemble model under climate change: A case for three invasive plants of Asteraceae. Sci. Total Environ. 2021, 756, 143841. [CrossRef] 
50. Sun, Q.; He, S.; Yang, X. Invasion status and countermeasures of two new exotic species in Guizhou. Guizhou Agric. Sci. 2010, 38, 90-92.

51. Sun, Q.; He, S.; Yang, L.; Zhou, H.; Xu, W.; Wang, Y. Xanthium mongolicum, a northeastern species is spreading rapidly in Guizhou and several southeastern provinces in China. Chin. Wild Plant Resour. 2010, 29, 21-22.

52. Kou, D.; Zhang, J.; Liu, X.; Li, Z.; Wang, P.; Sun, S. The invasion status and effect on plant diversity of Alternanthera philoxeroides in Aha reservoir in Guizhou. Guizhou Agric. Sci. 2012, 40, 129-132.

53. Zhang, J.; Cai, G.; Wu, D.; Li, Z.; Wang, J.; Yi, W.; Tu, S.; Tao, H. The plant community structure and quantitative features after the invasion of Alternanthera philoxeroides in Caohai Wetland of Guizhou Province. Ecol. Environ. Sci. 2018, 27, 827-833. [CrossRef]

54. Yang, Z.; Hu, Q.; Li, X.; Liu, T.; Zhang, N.; Qiu, J. Risk evaluation of Ambrosia trifida in Guizhou province. Guizhou For. Sci. Technol. 2017, 45, 1-5. [CrossRef]

55. Chen, S.; Ye, Z.; Ran, H.; Lan, X.; Zhou, P.; He, Y. Effect of different environmental condition on biological characteristics of Ageratum conyzoides, an exotic invasion weed. Guizhou Agric. Sci. 2018, 46, 64-66.

56. Tan, G.; Luo, Q.; Zhong, X.; Wang, T. The distribution and control measures of Cyclospermum leptophyllum in Guizhou. Agric. Technol. Serv. 2019, 36, 71-72.

57. Ban, Q.; Tian, M.; Yu, S.; Zhang, N.; Qiu, J.; Luo, N. Risk analysis of Mikania micrantha in Guizhou. Guizhou For. Sci. Technol. 2020, 48, 9-12. [CrossRef]

58. FAO; ISRIC; ISSCAS; JRC. Harmonized World Soil Database (Version 1.2); FAO: Rome, Italy; IIASA: Laxenburg, Austria, 2012.

59. Fick, S.E.; Hijmans, R.J. WorldClim 2: New 1-km spatial resolution climate surfaces for global land areas. Int. J. Climatol. 2017, 37, 4302-4315. [CrossRef]

60. Shi, H.; Cao, W.; Gao, Y.; Zhong, Q. Situation and control strategies of alien invasive plants in Northeast China grasslands Pratacult. Sci. 2016, 33, 2485-2493. [CrossRef]

61. Witt, A.B.R.; Kiambi, S.; Beale, T.; Van Wilgen, B.W. A preliminary assessment of the extent and potential impacts of alien plant invasions in the Serengeti-Mara ecosystem, East Africa. Koedoe 2017, 59, a1426. [CrossRef]

62. Martín-Forés, I.; Castro, I.; Acosta-Gallo, B.; del Pozo, A.; Sánchez-Jardón, L.; de Miguel, J.M.; Ovalle, C.; Casado, M.A. Alien plant species coexist over time with native ones in Chilean Mediterranean grasslands. J. Plant Ecol. 2016, 9, 682-691. [CrossRef]

63. Guido, A.; Vélez-Martin, E.; Overbeck, G.E.; Pillar, V.D. Landscape structure and climate affect plant invasion in subtropical grasslands. Appl. Veg. Sci. 2016, 19, 600-610. [CrossRef]

64. Datta, A.; Kuhn, I.; Ahmad, M.; Michalski, S.; Auge, H. Processes affecting altitudinal distribution of invasive Ageratina adenophora in western Himalaya: The role of local adaptation and the importance of different life-cycle stages. PLoS ONE 2017, 12, e0187708 [CrossRef] [PubMed]

65. Wan, F.H.; Liu, W.X.; Guo, J.Y.; Qiang, S.; Li, B.P.; Wang, J.J.; Yang, G.Q.; Niu, H.B.; Gui, F.R.; Huang, W.K.; et al. Invasive mechanism and control strategy of Ageratina adenophora (Sprengel). Sci. China Life Sci. 2010, 53, 1291-1298. [CrossRef] [PubMed]

66. Cui, Q.G.; He, W.M. Soil biota, but not soil nutrients, facilitate the invasion of Bidens pilosa relative to a native species Saussurea deltoidea. Weed Res. 2009, 49, 201-206. [CrossRef]

67. Blumenthal, D. Interrelated Causes of Plant Invasion. Science 2005, 310, 243-244. [CrossRef]

68. Burns, J.H. A comparison of invasive and non-invasive dayflowers (Commelinaceae) across experimental nutrient and water gradients. Divers. Distrib. 2010, 10, 387-397. [CrossRef]

69. Chen, M.; Jia, S. China Forage Plants; China Agriculture Press: Beijing, China, 2002.

70. Norris, I.B. Temperature response and flowering of white clover (Trifolium repens) varieties in controlled environments and the field. Ann. Appl. Biol. 1986, 108, 659-665. [CrossRef]

71. Britten, E.J. The influence of genotype and temperature on flowering in Trifolium repens. Agron. J. 1961, 53, 11-14. [CrossRef] 